\title{
The role of developing country multinationals in the acquisition of industrial technology in Nigeria : a pilot study
}

Citation for published version (APA):

Narula, R. (1997). The role of developing country multinationals in the acquisition of industrial technology in Nigeria : a pilot study. MERIT, Maastricht Economic Research Institute on Innovation and Technology. MERIT Research Memoranda No. 005 https://doi.org/10.26481/umamer.1997005

Document status and date:

Published: 01/01/1997

DOI:

10.26481/umamer.1997005

Document Version:

Publisher's PDF, also known as Version of record

Please check the document version of this publication:

- A submitted manuscript is the version of the article upon submission and before peer-review. There can be important differences between the submitted version and the official published version of record.

People interested in the research are advised to contact the author for the final version of the publication, or visit the DOI to the publisher's website.

- The final author version and the galley proof are versions of the publication after peer review.

- The final published version features the final layout of the paper including the volume, issue and page numbers.

Link to publication

\footnotetext{
General rights rights.

- You may freely distribute the URL identifying the publication in the public portal. please follow below link for the End User Agreement:

www.umlib.nl/taverne-license

Take down policy

If you believe that this document breaches copyright please contact us at:

repository@maastrichtuniversity.nl

providing details and we will investigate your claim.
}

Copyright and moral rights for the publications made accessible in the public portal are retained by the authors and/or other copyright owners and it is a condition of accessing publications that users recognise and abide by the legal requirements associated with these

- Users may download and print one copy of any publication from the public portal for the purpose of private study or research.

- You may not further distribute the material or use it for any profit-making activity or commercial gain

If the publication is distributed under the terms of Article $25 \mathrm{fa}$ of the Dutch Copyright Act, indicated by the "Taverne" license above, 
The Role of Developing Country Multinationals in the Acquisition of Industrial Technology

in Nigeria : A Pilot Study

Rajneesh Narula*

Summary

Forthcoming in Science, Technology and Development, Spring 1997

The growing presence of multinationals from developing countries (DC MNE's) has drawn some criticism regarding their ability to transfer technology. This paper seeks to examine whether, in the case of Nigeria, such MNE's utilise similar technology to that of Nigerian firms, and the implications for government policy on achieving technology transfer. Although tentative, the findings suggest that DC MNE's in Nigeria do not tend to acquire technology primarily from their home country, and suggests that although tangible technology that is transferred is similar to that directly acquired by domestic firms, there is nonetheless a difference in the nature in the intangible technology between the two groups

\section{INTRODUCTION}

The past two decades has seen an increasing number of developing countries moving away from an import-substituting regime towards an export-oriented one, often within the framework of a structural adjustment programme, and African countries have been no exception. However, Africa has not benefited from the rapid growth of FDI to developing countries, which have primarily been directed towards the newly industrialising economies of Asia and Latin America 10 of which accounted for $68 \%$ of total inflows to developing countries between 1980 and 1990 (UN 1992). Africa as a whole accounted for $8.6 \%$ of all FDI inflows to developing countries between 1981 and 1985, and even this share had fallen to 5\% between 1991 and 1994 (UNCTAD 1995). These represent the bulk of private capital flows to the African continent, and much of the capital needed to support their structural adjustment continues to come from official loans and grants (World Bank 1993, UNCTAD 1995). Much of this inflow is directed to a few countries, and generally towards the primary sector. Nigeria is perhaps the only exception in sub-Saharan Africa where $47 \%$ of FDI inflows between 1980 and 1990 were directed towards manufacturing.

\footnotetext{
* Dr. Rajneesh Narula is a Research Fellow at the Maastricht Economic Research Institute on Innovation and Technology (MERIT), Universiteit Maastricht, PO Box 616, 6200MD Maastricht, The Netherlands. The author wishes to acknowledge the support of Dr. Kofi Afriyie in developing and inspiring the questionnaire survey. Comments from Professor J.H. Dunning, and some anonymous referees are also gratefully acknowledged. Many thanks to Mr. M. Saqib, Mr. K.P. Bhutada and Alhaji Rilwanu for their invaluable assistance in administering this study. The usual disclaimer applies.
} 
Some of this growth in manufacturing has been as a result of the growth of developing country multinationals (DC MNEs ${ }^{1}$ ) - outward FDI stock from developing countries has increased substantially in value from $\$ 6.1$ billion in 1975 to $\$ 108.4$ billion in 1993 (current dollars) (Dunning, van Hoesel and Narula 1997). While even the most recent figure represented approximately $5 \%$ of global total outward FDI stock, the fact that it exists at all is of some significance. Recent studies such as Tolentino (1993) have illustrated the increasing industrial and geographical distribution of developing country MNEs. Although like industrialised country MNEs, an increasing number of DC MNEs are investing within the industrialised countries (Narula 1995), they nonetheless represent an important source of capital and technology flow to other developing countries that are undergoing the difficult process of economic transformation due to structural adjustment. Their role in African manufacturing is even more important given the increasing preference for industrialised country MNEs to concentrate on the primary and tertiary sector investments in Africa. Although official figures are unavailable, I estimate that about onethird of all manufacturing FDI stock is controlled by DC MNEs.

However, such inflows from other developing countries are often viewed as detrimental to the domestic manufacturing sector, as they are considered to have the same technological capabilities as domestic firms and not necessarily providing useful technological spillovers, especially in Nigeria. This paper seeks to examine this issue and evaluate whether there are significant differences in the technology employed by DC MNE's and their local competitors.

\section{THE EVOLUTION OF INWARD FDI IN NIGERIA}

Foreign investment has always played a major role in the Nigerian economy, although until 1972 much of the non-agricultural sector was controlled by large foreign owned trading companies which had a monopoly on the distribution of imported goods. It has been estimated that between 1963 and 1972, an average of 65\% of total capital was in foreign hands (Biersteker 1987). These firms consisted of mainly two groups. The first group, and by far the larger of the two were the European trading firms, while the second group consisted of Lebanese, Syrian and Indian origin owned firms The first group were primarily responsible for the local manufacturing operations and large scale wholesale trade. The second group tended to be responsible for small-scale wholesale distribution and retail trade. The European trading firms, it should be pointed out, can be considered as conglomerates, operating not just in trade and manufacturing, but in all sectors of the economy, including banking and insurance. 
Not surprisingly therefore, there was a widespread resentment amongst local entrepreneurs to this overwhelming presence of foreign capital. Although it was realised that in technology based sectors the capital as well as the technology were unavailable locally, the foreign domination of banking, insurance and trade was regarded as unnecessary and the presence of the foreign firms restrictive to the development of domestic competition $^{2}$. The result was the Nigerian Enterprises Promotion Decree of 1972, limiting foreign equity participation to sectors of manufacturing and commerce, as well as to a maximum of $60 \%$. It was also designed to improve the balance of payments position to a lesser dependence on imports by encouraging local value added in manufacturing and facilitating the technology transfer. Initially, it met with limited success, in part owing to the continued dominance of foreign firms in the commercial sector. In 1975 local firms represented $24.9 \%$ of the manufacturing sector as opposed to $20.2 \%$ in 1965 (Biersteker, 1987) This was despite the injection of capital into the economy resulting from the oil boom subsequent to the OPEC embargo of 1973. The United Kingdom accounted for $38 \%$ of the FDI in 1975, the U.S. 22\%, other Western European firms $26.0 \%$ and 'other' firms (primarily DC firms), 14\%. One-fifth of this investment was in the manufacturing industry. (Iyanda and Bello, 1979) While data is not available on inward direct investment in Nigeria broken down by home country and sector, in general, U.S. direct investment has been concentrated in the petroleum industry, whereas the manufacturing industry at that time was dominated by British and French interests, with DC MNE's principally being involved in trading and business services.

However, in 1977 a second decree was promulgated to fill in the gaps. Table 1 provides an indication of the growth of the manufacturing industry, based on the amount of value added undertaken by the Nigerian manufacturing industry. Perhaps as a result of this decree, the subsequent government encouragement of FDI, and the increased petroleum revenues, the manufacturing industry experienced phenomenal growth during the late 1970 's. This growth tapered off by the early 1980's, again due in part to the reduced earnings from petroleum. However, by 1982 about $40 \%$ of all manufacturing was domestically owned $^{3}$. Direct investment in manufacturing between 1975 and 1982 increased from N543.1 million to N1922.5 million in current terms. ${ }^{4}$ The U.K. accounted for approximately $28 \%$, the U.S. $12 \%$, Western Europe $35 \%$ and 'other' (third world) countries $25 \% .^{5}$ 
Although this represented sizeable investment in financial terms, it had primarily been in final assembly and secondary processing, which required heavy dependence on imports for raw materials and intermediate goods which were necessary as inputs for most manufacturing firms. For instance, the local transport equipment industry was dependent on Completely Knocked Down (CKD) kits imported from the parent companies' home country - imports in this industry account for $95 \%$ of all inputs. With severe balance of payments problems after 1982, there was little fresh investment, especially from industrialised countries, as the exchange rate worsened and the availability of foreign exchange became increasingly restricted. Much of the investment made after that time by firms from industrialised countries has been involuntary due to difficulties in repatriating earnings in hard currency.

Since 1984 the Nigerian government has had a policy to force manufacturers to invest in local raw materials, but this has been largely unsuccessful. ${ }^{6}$ After 1982, the manufacturing industry shrunk : the index of manufacturing production fell from 432.7 in 1982 (with $1972=100$ ) to 323.5 in 1986 (CBN Monthly Reports, various editions). Further, since the mid-1980's a number of European firms have divested their investment in Nigeria due to the high uncertainty in the Nigerian market as well as payment difficulties. The developments in Europe with regards the EC have accelerated growth there, and this has meant that investors from European countries are even less prone to invest in Nigerian manufacturing, although investment in the petroleum industry remains vigorous. A large number of the manufacturing facilities divested have been taken over by DC firms, especially those from India, Pakistan, Lebanon and Hong Kong. ${ }^{7}$ In terms of significance, the Indian and Pakistani firms account for about $75 \%$ of the total DC manufacturing firms, whereas the Lebanese-controlled firms account for $10 \%{ }^{8}$

In September 1986 the government undertook the Structural Adjustment Program (SAP) which has led to a restructuring of the Nigerian Economy. This entailed the abolition of the import licensing system, reduction and adjustment of import duties and tariffs, as well as the introduction of the Second Tier Foreign Exchange Market (SFEM) leading to the devaluation and managed float of the previously-pegged Naira. However, this has resulted in higher unit production costs, given the dependence on imports for inputs. The government has also begun to stress more on primary production, especially agriculture related investments. However, some recovery has been made by the manufacturing industry, as a result of tariff cuts and the removal of most restrictions on foreign ownership ${ }^{9}$, It is estimated that by the end of 1989 the book value of foreign direct investment in Nigeria was between N12 and 15 billion, of which about one third is in manufacturing. As mentioned earlier, much of this has, with the waning interests of small and medium scale European 
investors, been acquired by DC MNE's. It has been estimated that. about one-third of the total manufacturing investment in Nigeria is owned or controlled by Indian and Pakistani firms. ${ }^{10}$

\section{ANALYTICAL FRAMEWORK}

Technology transfer is perhaps the single most important issue when equity based $\mathrm{FDI}^{11}$ is considered relative to the other main options for investment such as licensing, technology contracts and turnkey operations.

Technology transfer is generally examined against the following criteria (UNCTC 1988) : (a) the extent to which technology is diffused into the host country, (b) the transfer of skills, (c) the stimulation of local technological activities, and (d) the appropriateness of the technology being transferred.

There has been a lack of consensus of what actually constitutes technology (Afriyie 1988). Technology can take numerous forms but can be regarded as consisting of two main types (Figure 1):

1. Codifiable technology : This refers to technology that can be identified and collated and transmitted from one user to another through the use of manuals or may be incorporated into physical tangible assets. These can be classified into two categories :

i. Tangible assets - consists of such assets as machinery and equipment, spare parts etc., or what is normally referred to as 'hardware'.

ii. Tangible knowledge - Examples would include blueprints, manufacturing process techniques, other tangible knowledge associated with a production system, or services including acquisition of crucial specific resources (i.e. the acquisition of all intermediate goods and products). This type of technology is often referred to as 'software'.

2. Non-codifiable Technology forms the second main kind of technology and consists primarily of intangible knowledge. This consists of technical manpower and the intangible assets associated with such skilled labour such as marketing know-how, product and process design and adaptive knowledge. 
From the policy-makers perspective, technology can be acquired by domestic firms either through arms-length arrangements by a local entrepreneur or though the use of external markets by contractual means. There are any number of ways this can be organised. One method is the use of turnkey contracts with a foreign firm or consultant to provide the tangible assets and knowledge, and a technical contract with yet another firm to provide the skills or non-codifiable intangible assets. A second method is through joint ventures (JV) - a complete technology 'bundle ${ }^{12}$ is provided by the foreign partner in exchange for equity and/or management participation. The first approach has the benefit of maintaining indigenous control. On the other hand, the acquisition of technology in the unbundled form requires the availability of a minimum technical infrastructure to the firm (such as technicians with the appropriate training and experience) to accomplish the effective and efficient 'unbundling'. This may not be locally available for all sectors of industry, thus resulting in the acquisition of inappropriate technology by the indigenous firm.

The use of FDI in a JV means that it is possible to negotiate the technological 'bundle'. It has also the advantage that the foreign partner has vested interest in the success of the JV. The disadvantage of foreign participation is that once the JV has been set up, the foreign firm may either not transfer the technology, or compete aggressively with struggling domestic entrepreneurs based on the superior technology it possesses, preventing the growth of indigenous technological capacity. It is for this reason that countries such as Brazil and Korea have set up strict controls to allow for such transfers as well as compulsory indigenization schemes that gradually dilute the share of foreign participation as the technology is transferred. However, it is generally assumed that such FDI is usually in industries in which there are no local competitive advantages to exploit.

While 'conventional' industrialised country MNE's that operate in DCs do not fall into a well-defined category there are nevertheless certain general set of common characteristics: that of large size, relatively capital-intensive manufacturing processes, high level of skill, differentiated products, advanced marketing techniques. As such there is rarely an immediate problem of these firms competing with domestic firms.

In the case of DC MNE's this may not necessarily be the case. Various scholars including Wells (1983), Lall (1983) and Lecraw (1981) have pointed out that such firms tend to differ significantly from conventional MNE's in the proprietary advantage they possess. In general, they have tended to operate with small scale manufacturing, producing low-volume, labour-intensive output that is rarely differentiated. These firms tend to use second hand machinery as well as equipment from their home country which is generally more 'appropriate' (Lecraw, 1977). 
The level of technology used by DC MNE's is thus closer to that available in the host country, in terms of the created factor endowments. This in itself is no revelation given the relative developmental stages of both home and host country. There is however the argument that this technology that is transferred by such firms is in fact already obsolete even in the host country, or that it is sufficiently similar to that already possessed by local manufacturers through external markets as makes no difference. This infers therefore that DC MNE's are in fact not providing technology but capital, supplanting and therefore competing against domestic manufacturers. It has even been argued that the distinctive modus operandi of DC MNE's, viz., small scale labour-intensive manufacturing, is not necessarily evidence of adaptation of more advanced technology to suit the factor endowments of the DCs but may in fact be evidence of a lack of innovatory capacity (Lall 1983).

\section{THE RESEARCH QUESTIONS}

We have demonstrated above the important role that foreign investment has played since independence, and the changing nature of the economy. While most of the foreign direct investment has been from the U.K., France, U.S. and other developed countries, there has been a gradually increasing presence of DC firms. Moreover, much of this investment is in the manufacturing sector, while a large proportion of the investment by developed countries is in the primary sector, especially petroleum. Given the historical suspicion in which DC firms are held, i.e., that they possess skills and tangible technology that available locally and are therefore making above normal profits based on better access to capital, and their sustained and growing presence (Biersteker 1987, Onimode 1982), it is germane to enquire whether or not differences exist in the acquisition of technology variables during the period in question.

In other words, is there any justification in the premise that third world joint ventures operate manufacturing firms using technology variables available to (and therefore at the expense of) local entrepreneurs, and owe their presence to market imperfections in the local capital markets that such firms are able to circumvent through their access to foreign capital? Secondarily, insofar as we can conclude from the circumstantial evidence provided through this study, does industrial policy in Nigeria at the time inhibit or aid the development of the manufacturing sector and the development of indigenous capabilities?

The specific questions we are asking can be stated as follows: 
1. What differences are there in their operating profile? Do Wholly Owned Nigerian (WON) firms compete with firms that have foreign participation? It is germane too, to examine who the primary competitors are since Nigerian industrial policy during the period in question seems to suggest that JV's may exist where Nigerians do not possess the relevant technology and to encourage foreign firms in sectors where no local industrialists operate, and as that industry 'matures' in a Nigerian context, to decrease the level of domination of foreign firms over time. Further, both WON firms and DC MNEs would be protected from imports by government restrictions, in line with the import substituting policy. The existence of government protection and incentives would be an indicator of such 'infant industry' protection. We therefore hypothesise that WON firms have as their primary competitors other domestic firms ${ }^{13}$ and, whereas, foreign firms would compete mainly with other foreign firms. Given the 'import substituting' policy pursued by the Nigerian government, neither would be faced with effective competition from imports, since tariff barriers to imports would exist.. This would imply that JV's would face an oligopolistic market and be able to extract monopoly rents or at least abnormal profits as an incentive for direct investment in an industry which the government wishes to develop, and more intense competition in more mature industries.

2. What are the sources of the technology variables being used? Are the DC firms using the same or similar technology in their operations as domestic Nigerian firms, and what sources are they being acquired from? Based on our earlier definition of technology into three essential components, we shall examine the nature and source of the following three variables as proxies for these major components:

Capital equipment [tangible codifiable assets]- what sources are used by DC firms - do they in fact differ from those used by WON firms? If the source is the same, do they differ in any way through modification or adaptation? It is hypothesised that JV's would adapt more than wholly owned Nigerian firms.

Intermediate goods [tangible codifiable knowledge]- what sources are used to acquire these. To what extent are local raw materials and intermediate goods used, given the governmental emphasis on local content. It is hypothesised that DC MNEs will have a preference for intermediate goods from their home countries.

Labour/skilled manpower [intangible non-codifiable knowledge]- To what extent is technology dependent on local skills or expatriate skills. We will examine the ratio of 
expatriates to Nigerian technical personnel as a proxy for technical manpower. It is hypothesised that this ratio will be higher for JV's than for WON firms.

\section{THE SAMPLE}

This study was undertaken during the period 1988-1990. A questionnaire was distributed to companies involved in the manufacturing sector directly to the production manager or general manager of the company. Companies targeted were involved in small to medium scale manufacture. Given the low response rate normally achieved by mailings and the relatively small population of DC MNE's in manufacturing, it was decided to solicit responses by directly approaching the respondents through a number of executives14, all of whom were at the time involved in management of such enterprises. Therefore, they were in a position to assist in the development and implementation of the questionnaire. Of the 120 questionnaires distributed, 32 were completed and returned. Additional information was acquired through telephone and personal interviews.

Of the 32 firms, 15 are WON firms and 17 are JV's. As mentioned above, all are involved in small or medium scale manufacturing and are concentrated in light manufacturing All the firms had been in operation for at least 5 years, with the oldest having been incorporated in 1965. Thus they may be regarded as part of the 'new' entrants into manufacturing, and not part of the older trade-and-distribution conglomerates, though undoubtedly some do have some connection with them. The distribution of nationality of JV's closely approximated that of the universe of DC manufacturing firms: 10 were Indian/Pakistani, 2 Hong Kong, 2 Taiwanese, 2 Lebanese and 1 firm of East African origin $^{15}$. Given the small sample sizes, we are unable to test hypotheses using standard statistical techniques.

It should be pointed out that while the sample size is small, when compared to the universe of JV's in Nigeria that can be identified as JV's from developing countries, the sample contains a high proportion of all such firms ${ }^{16}$. Nevertheless, it is felt that this study is of a suggestive nature and provides valuable information as to future direction for further research.

\section{RESULTS AND DISCUSSION}

\section{General profile}


All the firms in the sample were either of small or medium scale of operations involved in light manufacturing or assembly. Table 2 provides indicators for size by ownership type - whether WON or JV using three different indicators of size - turnover, number of production workers, and number of technical managers. There does not seem to be any significant difference in the mean or standard deviation between the two groups. Overall, this information would suggest that DC MNE's operate on a similar scale to that of local firms.

\section{[TABLE 2 ABOUT HERE]}

\section{Competition}

The respondents were asked to rate the intensity and sources of competition. All WON firms rated the competition they faced as being 'intense' as compared with only $23.5 \%$ of JV's (Table 3 ). Table 4 gives the breakdown of the sources of their competition. While no clear pattern is suggested from the results, WON firms seemed to consider as their primary competition other WON firms and smuggled goods. Only 30\% considered JV's as an important source of competition. In the case of the DC MNEs, only $46.2 \%$ considered Nigerian firms as a main source of competition. 84.6\% of JV's regarded other JV's as the main source of their competition. Again, our sample size prevented us from identifying whether there was any overlap in the industry of operation of these respondents.

\section{[TABLE 3 AND 4 ABOUT HERE]}

\section{Government Protection and Incentives}

None of the 15 WON firms in our sample received any form of government incentives such as tax holidays, tariff protection etc., whereas 4 of the JV's received some form of government incentives. Three of these were in the metal fabrication industry and the fourth involved in assembly of electrical machinery. All four firms had some degree of government equity participation at either the state or the federal level. In our sample, 8 out of the $17 \mathrm{JV}$ 's had some government equity participation while none of the WON firms had any. Why only 4 of the 8 received government incentives may have something to do with a variety of factors such as industrial concentration in the state of operation and the percentage of government participation. These took the form of tariffs against foreign imports. However, during the interviews, 2 of the 4 firms that received some protection complained that the tariff structure was uneven and even unfair to local production - while 
tariffs had been raised on imports, the unassembled item that these firms imported faced a higher tariff! ${ }^{17}$

Nevertheless, some elements of the implied government policy seem to be working in that domestic and foreign firms seem to not compete directly, therefore tentatively suggesting that industrial policy of separating industry of operations is working, although we are unable to ascertain whether these are in fact in the same industries that the policy was designed to protect.

\section{Capital Equipment}

While the export of capital equipment from the home country has been described as an important benefit derived by the DC MNE (Agrawal 1981, Khan 1986), it is not applicable in the context of our sample. Only one JV imported equipment from its home country. Further details are set out in table 5.

\section{[ TABLE 5 ABOUT HERE]}

All the Nigerian firms imported their equipment from Western Europe, compared with $58.8 \%$ of JV's. Other sources used by JV's were Japan and the U.S. While this may again be a function of the industry of operation, JV's were found to be more selective in the acquisition of technology. One of the JV executives interviewed explained that the main reason for acquisition of capital equipment from developed countries as opposed to the home country were proximity, as well as a wider selection of high quality second hand and new equipment. The two cases of equipment importation from the home country were the cases of manual metal fabrication equipment of a type no longer easily available in developed countries.

This would suggest that DC firms have acquired knowledge on the most efficient (both economically and technically) sources of equipment through operations in other locations, and are thus able to utilise this experience in making rationalised purchases of capital equipment. As Wells (1983: 29) observes,

A few firms in the developing countries have made the large investment required to learn about a wide range of equipment - they not only have collected specifications, but have tried the equipment for reliability and know the availability of spare parts. Once acquired, such knowledge is useful in other small markets. 
White (1981) observes a similar phenomena amongst Latin American MNE's much of the capital equipment are imported, he observes, but because of the learning process they have undergone in the home country the MNEs are aware of the most appropriate equipment and have the necessary specialists to operate and modify them. The outright preference of WON firms for western Europe may point to the inadequacy of the sample size - perhaps with a larger population there might be some variance. On the other hand, it may be possible that some of these firms bought a 'technology bundle' under a turnkey agreement. Such agreements tend to occur more readily with firms from western Europe given the strong economic relationship with firms from these countries due to historical as well as cultural ties.

Lecraw notes that given the labour-intensive nature of DC firms' manufacturing operations, much of their equipment was acquired from the home country, this being because such equipment was obsolete and no longer available from developed countries which had been the original sources of this equipment. Its manufacture had thus been relocated further downstream and had been 'lost' among developed country firms. Nambudiri et al (1981), on the other hand, in a similar study to the present one, found that third world JV's in Nigeria tend to use the same equipment as conventional MNE's so as to compete on equal terms with them. The case of Nigeria is therefore perhaps an exception to the rule: it has been estimated (Monkiewicz 1986) that $80 \%$ of DC MNE technology is supplied by the home country.

\section{Adaptation}

It is axiomatic that imported capital equipment will require some extent of modification for them to work efficiently in the Nigerian context. respondents were asked how much and to what level is adaptation of such capital equipment was done. This is a dilemma that faces firms operating in third world contexts vis-à-vis hardware. Should firms install state of the art equipment (often encouraged by the host government) which requires a minimal skilled labour input to operate it, but an even higher skilled manpower to maintain it? Or should the firm install labour-intensive equipment which requires a minimum of skilled labour to operate, maintain and repair, but result in being accused by the host government of transferring obsolete skills? Further, there is the added complication that automated equipment is developed for high volume production and is not cost efficient for small production runs ${ }^{18}$. The capital intensive scenario involves the issue of maintaining expensive expatriate staff to provide technical support or the equally expensive alternative route of maintenance contracts with third parties ${ }^{19}$. 


\section{[TABLE 6 ABOUT HERE]}

Table 6 demonstrates that over $90 \%$ of WON firms adapted their capital equipment 'frequently' or 'always' compared to $5.9 \%$ of JV's. The majority of the JV's claimed that they 'occasionally' adapted. This appears at first to be contrary to conventional wisdom given that the source of the equipment is the same. However there are two possible explanations for this. Firstly, it could reflect an ability on the part of the $\mathrm{JV}$ to acquire the most appropriate equipment available on the market thus requiring minimal adaptation, due to their experience in capital equipment acquisition. Secondly, given the fact that JV's have a higher ratio of expatriates to Nigerian personnel than WON firms, and therefore implying a greater access to technically skilled manpower, it may not be imperative that adaptations are done as they have on-site the skills to maintain the equipment, compared with WON firms which might be constrained by availability of technical manpower. The second argument is weak however, since it should be easier for DC firms to adapt equipment, as familiarity with maintenance/techniques goes hand in hand with knowledge of adaptation.

\section{Technical Manpower}

Using the ratio of expatriates to Nigerian technical personnel as a proxy to measure this, Table 7 shows that Nigerian firms in general had less than a $20 \%$ ratio of expatriate to Nigerian technical personnel. $70.6 \%$ of the JV's had a $20-50 \%$ ratio and $11.8 \%$ had a $50-100 \%$ ratio. Clearly, JV's maintained a higher percentage of foreign technical staff. While it was expected that this would relate to the industry of operation, no causal relationship was apparent. This may be due to the fact that the allocation of expatriate quotas for foreign firms is a sensitive and highly political issue The allocation of expatriate quotas are made based on the perceived need of the particular project as well as the political importance of the project. The data may also be skewed as a number of firms bring in expatriate personnel for management positions under a technical position allocation.

\section{[TABLE 7 ABOUT HERE]}

Nonetheless, the ratio still remains quite high. Lecraw (1981) notes a propensity of DC firms to hire a larger number of expatriates than conventional MNE's. While this may 
indeed be the case of DC firms in Nigeria too, the scope of our work does not include a comparison with conventional MNE's.

\section{$\underline{\text { Intermediate Goods }}$}

Table 8 provides details of the primary source of intermediate goods for the operations. WON firms overwhelmingly acquired intermediate goods from Europe (80\%), with the rest coming from Japan. Imports from Japan were primarily fabricated metal products such as steel sheets, an area in which Japan possessed significant competitive advantages.

\section{[TABLE 8 ABOUT HERE]}

Joint ventures' imports of intermediate goods were more evenly spread out geographically, with $52.9 \%$ from Europe, $41.8 \%$ from Japan and 5.9\% from eastern Europe. This greater spread of sourcing suggests more premeditation and experience in acquiring resources, as opposed to the case of WON firms which apparently use traditional and therefore more convenient sources (although not necessarily more efficient).

Agrawal (1981) states that the relatively low profit margins of Indian firms vis-àvis conventional multinationals are offset by the sourcing of intermediate goods and capital equipment from the home country, and usually from the parent company. This study again casts doubt on this explanation. In fact our study indicates that these firms, as would firm of industrialised country origin, base their decisions on sound economic rationale, as opposed to altruistic and patriotic considerations. Furthermore, transfer pricing can be practised through a third country, and has been known to be executed through collusion with parties not affiliated with the multinational.

\section{SUMMARY AND CONCLUSIONS}

Our study has been primarily concerned with asking the following: (i) are DC multinationals operating with essentially the same technology as their domestic counterparts?, and (ii) are these firms therefore operating in Nigeria in direct competition with (and in detriment to) Nigerian firms ?

The evidence presented in the previous section suggests a number of interesting results which are summarised below: 
a. There was no clear difference in size of operations of either group of firms, or any clear incentive or protection provided by the government to promote or discourage competition

b. Both JV's and WON firms acquired most of their capital equipment from industrialised countries. The clear preference by DC MNE's against home country acquisition suggests that such firms' policies are based on a profit maximising principle and is done to minimise costs, as well as to compete effectively with conventional MNE's who use similar equipment.

c. DC MNE's do not undertake as much adaptation of their capital equipment as WON firms. This suggests that either these firms are able to acquire appropriate equipment or that, because they have a higher number of expatriate technical personnel used to maintaining such equipment, they tend not to regard adaptation as important.

d. JV's employ a higher percentage of expatriate personnel than WON firms.

e. Just as with capital equipment, intermediate goods were not acquired from the DC MNE's home countries, but seemed to be selected on criteria other than the country of origin.

This evidence presented in this study suggests that there are some clear differences in the way technology is acquired and configured by DC MNE's and Nigerian firms.

\section{[FIGURE 2 ABOUT HERE]}

Figure 2 shows schematically the relationship between technology flows, DC MNE's host, and source countries. Our study would suggest that technology is acquired by DC MNE's through a global scanning process in a rationalised and efficient manner, and based on experience of acquiring these same technology variables for operations elsewhere. Thus few benefits, as have been described in the literature, accrue to the parent company through sales of intermediate goods and capital equipment, at least in the case of DC firms in Nigeria. The DC MNE is not in the business of maximising benefits of its home country, but its own - it acquires various elements of technology in the most efficient way (in an economic sense) it knows how, regardless of country of origin. 
Further, this study suggests that while the scale and industry of operations are similar, the technology used by JV's of DC origin, although not necessarily proprietary, is 'different' in that it has been 'bundled' after being 'unbundled' in other locations. This results in a lesser need to adapt the equipment, and reduces the cost of operation, although this reduction in costs is probably partly offset by the cost of maintaining a larger expatriate staff. Nigerian industrial policy, at least to the extent that infant industry protection is undertaken seems to be effective. However, other measures such as government protection and incentives are not, and seem less to be a function of infant industry protection, but one of political protection - there seems to be a haphazard way of providing protection by industry. Again, this remains a tentative conclusion given our severely restricted sample size. Measures offered as incentives such as tariff barriers to imports have often been contradictory and are detrimental to the development of an import substituting manufacturing industry.

As to the acquisition of technology, we were able to observe that JV's were more selective in their sourcing of capital equipment and intermediate goods as compared to WON firms. While we are unable to say as to whether or not technology is being transferred, for clearly this study would suggest that the edge that the DC MNE possesses in the Nigerian context is that of non-codifiable and intangible knowledge. It is the experience of operating similar plants under similar circumstances and conditions in other countries that gives them this edge, and not through access to particular tangible assets or knowledge per se - the ownership of knowledge of the 'where' of the technology and not necessarily the 'how'. Naturally, this is somewhat of a generalisation, for at least two JV's acquired the use of the foreign partners brand name, which would suggest that accepted wisdom re that DC multinationals tended to produce undifferentiated goods, it also implies the existence of proprietary knowledge that distinguished its goods from other similar goods i.e., the existence of tangible, codifiable knowledge. It should be emphasised that this indicates, at most, an ability to master proprietary knowledge in certain technologies, and the ability to adapt it to the special needs of developing country conditions, and does not necessarily suggest that such companies have developed and created new technologies. ${ }^{20}$

It may be argued that such technology is more 'appropriate' to the stage of development of the host country. However, it would be interesting to compare both DC MNE's and WON firms with conventional MNE's before stating whether one particular kind of firm uses more appropriate technology then the other. If the results of our study were replicated over a larger sample, it would also provide (limited and perhaps superficial) support to the critics of DC MNE's, viz., that they use technology that is 
available through the market and similar to that used by local entrepreneurs, and thus are simply taking advantage of their lower cost of capital, a result of their multinationality.

Overall, the results that have been provided here would indicate very weakly some possible trends that are applicable, and suggests avenues for further research.

\section{IMPLICATIONS FOR POLICY-MAKERS}

These results, if they were to hold true for a larger sample, would provide valuable implications for policy-makers. Firstly, that there is a difference in the technology being used by DC MNE's and WON firms, albeit a non-codifiable one. As such, they are unlikely to provide 'destructive' competition to domestic infant industry if they were to operate in the same industries. Indeed such competition may force domestic firms to operate more efficiently in order to compete with these firms.

On the issue of technology transfer then, clearly, since the technology to be transferred is non-codifiable it is thus more difficult to impart, and as a result, such skills would necessarily require the availability of well-trained personnel to understudy over a period of time, the technical personnel of the JV. Indeed this has been the policy of the Nigerian government and appears in principle to be sound.

Again, it is a deficiency of this study in not making a three-way comparison that included conventional MNE's. It would be interesting to see if indeed there exists a threetier technology ecosystem - conventional MNE's in the upper most tier possessing competitive advantages in both tangible and intangible technology, DC MNE's in a lower tier, which have acquired tangible technology from the developed countries but possess their own intangible technology, and the third tier being that of domestic firms attempting to develop the intangible technology, while presently acquiring both the tangible and intangible technology from the other two tiers.

It is for policy-makers to decide whether or not to acquire technology that has been 'unbundled' by the DC MNE and 're-bundled' for use in Nigeria or other developing countries, or whether to attempt to do this directly from developed country firms, and whether the additional time this would take to develop this intangible knowledge is worth the opportunity cost in the appropriate cost-benefit analysis. 


\section{REFERENCES}

Afriyie K., 1988, Strategic Paths To Technology Acquisition and Transfers in International Cooperative Ventures, Rutgers Graduate School of Management Working Paper \#88-009 (Newark: Rutgers University).

Agrawal, R.G., 1981, 'Third-World Joint Ventures : Indian Experience', in Kumar, K. and McLeod, G. (eds.): Multinational from Developing Countries (Lexington: DC Heath).

Ash, N., 1988, 'Nigeria', Euromoney special supplement, September.

Bello J.A. and O. Iyanda, 1981, Appropriate Technology Choice and Employment Creation by Two Multinational Enterprises in Nigeria, Multinational Enterprises Programme Working paper No. 17 (Geneva: ILO).

Biersteker T., 1987, Multinationals, The State, and Control of the Nigerian Economy, (Princeton: Princeton University Press).

Central Bank of Nigeria (vd) Annual Report, various issues.

Central Bank of Nigeria (vd) Monthly Report, various issues.

Central Bank of Nigeria (vd) Economic and Financial Review, various issues.

Dunning, J.H., R. van Hoesel and R. Narula, 1997, 'Explaining the 'new' wave of outward FDI from developing countries', International Business Review, forthcoming.

Economic Commission for Africa, 1988, Survey of Economic and Social Conditions in Africa 1986/87 (New York: United Nations).

Economist Intelligence Unit - Country Report, Nigeria, various editions.

Il\&T, 1989, Nigeria, Business International Corporation, April.

Iyanda, O. and J.A. Bello, 1979, Employment Effects of Multinational Enterprises in Nigeria, Working paper No.10 (Geneva: ILO).

Khan K.M., 1986, Multinationals From the South: Emergence, Patterns and Issues, in Khan K.M. (ed.), Multinationals from the South, (London: Francis Pinter).

Kumar, K. and McLeod, G.M., 1981, in Kumar, K. and McLeod, G. (eds.): Multinational from Developing Countries (Lexington: DC Heath).

Lawn, M. (ed.), 1988, Major Companies of Nigeria 1982 (London: Graham \& Trotman Limited). 
Lall, S. (ed.), 1983, The New Multinationals (Paris: IRM Press).

Lecraw, D., 1981, 'Internationalization of Firms from LDCs : Evidence from the ASEAN Region' in Kumar, K. and McLeod, G. (eds.): Multinational from Developing Countries (Lexington: DC Heath).

Lecraw, D., 1977, 'Direct Investment By Firms from Less Developed Countries', Oxford Economic Papers, pg. 442-457.

Masini J., M. Ikonicoff, C. Jedlick and M. Lanzarotti, 1980, Multinationals and Development in Black Africa (New York: Praeger).

Monkiewicz, J., 1986, 'Multinational Enterprises of Developing Countries: Some Emerging Characteristics', Management International Review, vol. 26, 1986/3, pg. 67-79.

Nambudiri, C.N.S., 1983, Third World Multinationals : Technology Choice and Employment Generation in Nigeria, Multinational Enterprises Programme Working Paper No. 25 (Geneva: ILO).

Nambudiri, C., O. Iyanda and D. Akinnusi, 1981, 'Third World Country Firms in Nigeria' in Kumar, K. and McLeod, G. (eds.), Multinational from Developing Countries (Lexington: DC Heath).

Narula, R., 1995, Multinational Investment and Economic Structure (London: Routledge).

Onimode, B., 1982, Imperialism and Underdevelopment In Nigeria (London: Zed books).

Tolentino, P.E., 1993, Technological Innovation and Third World Multinationals (London: Routledge).

UNCTAD, 1995, Foreign Direct Investment in Africa (Geneva: United Nations).

UNCTC, 1988, Transnational Corporations and Technology Transfer : Effects and Policy Issues (New York: United Nations).

UNIDO, 1988, Africa in Figures (New York: United Nations).

United Nations, 1992, World Investment Report 1992 (New York: United Nations).

Villela A., 1983, 'Multinationals from Brazil' in Lall, S. (ed.), The New Multinationals (Paris: IRM Press).

Wells, L.T., 1983, Third World Multinationals (Cambridge: MIT Press). 
White, E., 1981, 'The International Projection of Firms from Latin American Countries', in Kumar, K. and McLeod, G. (eds.), Multinational from Developing Countries (Lexington: DC Heath).

World Bank, 1993, World Debt Tables 1993-94 (Washington: World Bank) 


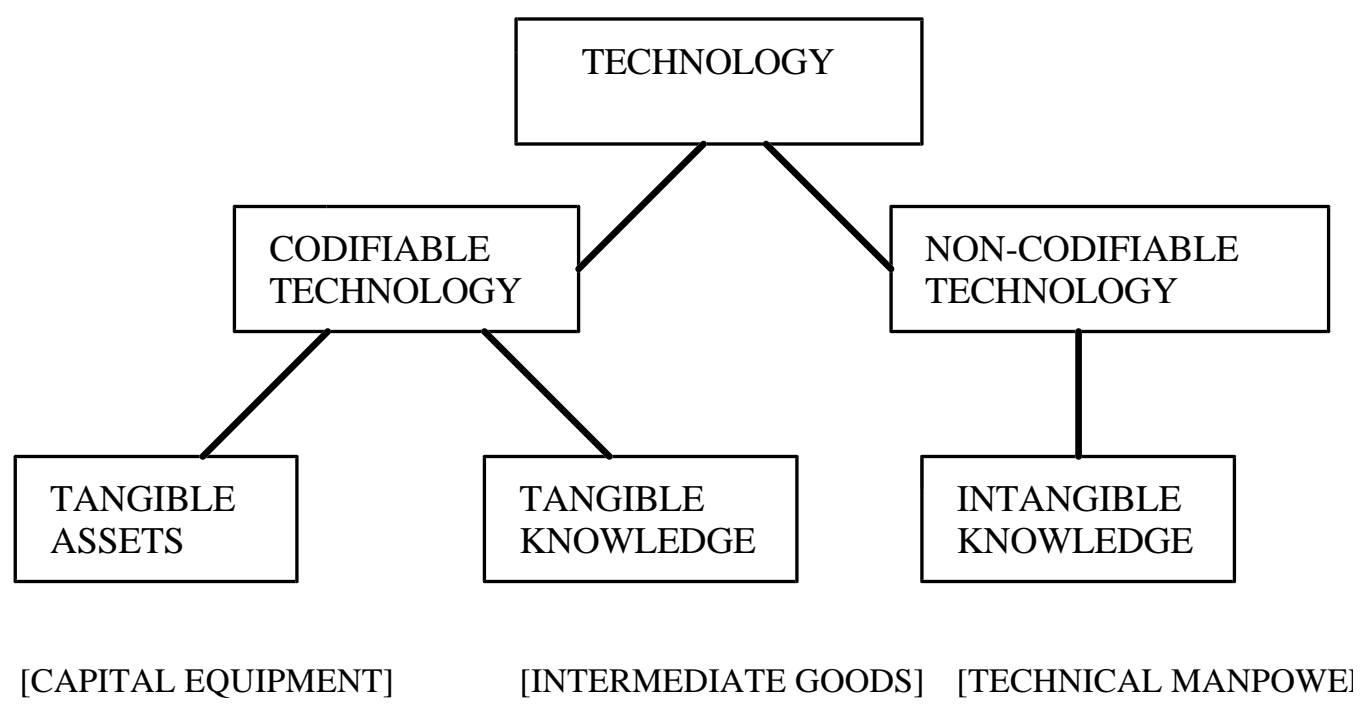

Figure 1: A Definition of Technology 


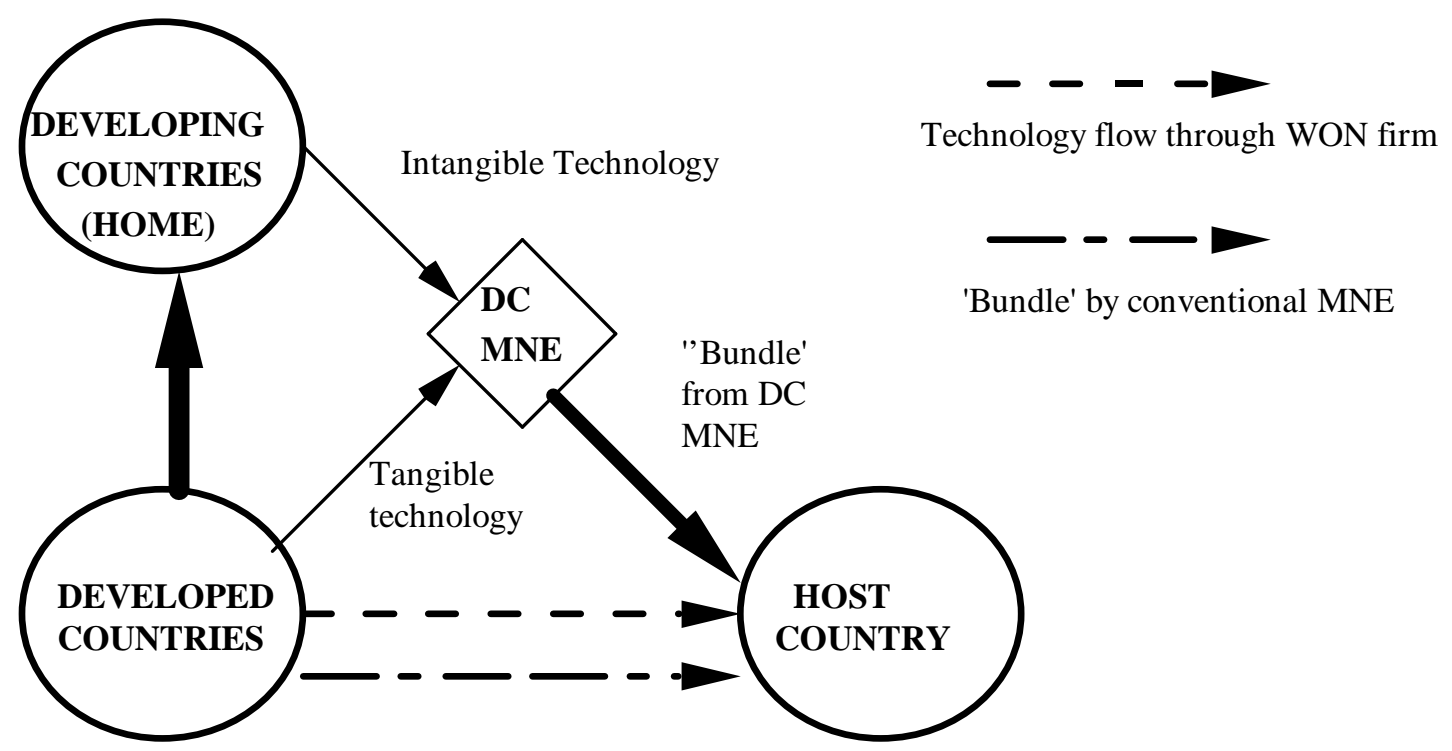

Figure 2: Technology Flows and the Role of the DC MNE 
Table 1: Value Added in Nigerian Industry

\begin{tabular}{llll} 
& \multicolumn{3}{c}{ U.S.\$ millions (current) } \\
INDUSTRY & 75 & 80 & $85^{*}$ \\
Non Elect m/c & 6 & 61 & 122 \\
Elect m/c & 31 & 113 & 224 \\
Transportation & 22 & 424 & 842 \\
Industrial chem & 15 & 35 & 68 \\
Iron and steel & 2 & 20 & 29 \\
Metal products & 164 & 353 & 689
\end{tabular}

* estimated by UNIDO

Source: Economic Commission for Africa: (1988)

Table 2: Comparison of General Profile Indications of Size and Technology Level

\begin{tabular}{lccc} 
& & JV & WONF \\
\hline Turnover $^{I}$ & $\mathrm{x}$ & 2.69 & 2.8 \\
& & 0.85 & 0.92
\end{tabular}

No. of Production $\quad \mathrm{x} \quad 246.33 \quad 227.90$

$\begin{array}{lll}\text { Workers } & 167.59 & 147.85\end{array}$

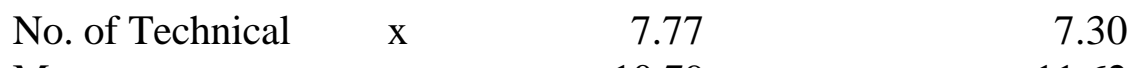

$\begin{array}{lll}\text { Managers } & 10.79 & 11.62\end{array}$

$\begin{array}{lll}\text { No. of Non-technical } \mathrm{x} & 4.69 & 6.2\end{array}$

$\begin{array}{lll}\text { Managers } & 6.02 & 11.91\end{array}$

1 The turnover estimates are for the year 1986

The scale used for turnover is as follows :

$$
\begin{aligned}
& 1=\text { less than Naira } 1 \text { Million } \\
& 2=\text { between Naira } 2 \text { and } 5 \text { million } \\
& 3=\text { between Naira } 5 \text { and } 10 \text { million } \\
& 4 \text { - greater than Naira } 10 \text { million }
\end{aligned}
$$

WONF $=$ Wholly Owned Nigerian Firm

$J V=$ Joint Venture (with a DC MNE)

Source: Primary data 


\section{Table 3: Degree of Competition Experienced}

"How Would You Rate the Competition Facing your Company?"

\begin{tabular}{llrrr} 
& \multicolumn{2}{c}{ JV } & \multicolumn{2}{c}{ WONF } \\
\hline Relative Intensity & $\#$ & \% & $\#$ & \% \\
\hline 1. Intense Competition & 4 & 23.1 & 15 & 100.0 \\
2. Moderate Competition & 9 & 53.9 & 0 & 0.0 \\
3. Very Little Competition & 4 & 23.1 & 0 & 0.0 \\
4. No Competition & 0 & 0.0 & 0 & 0.0 \\
TOTAL & 17 & 100.0 & 15 & 100.0 \\
WONF = Wholly Owned Nigerian Firm & & & \\
JV = Joint Venture (with a DC MNE) & & & \\
Source : Primary data & & & \\
\end{tabular}

Table 4: Sources of Competition (Multiple responses allowed)

\begin{tabular}{|c|c|c|c|c|}
\hline "Our primary & & & & \\
\hline competitors are :" & $\#$ & $\%$ & $\#$ & $\%$ \\
\hline 1. Nigerian Firms & 6 & 46.15 & 11 & 90.00 \\
\hline 2. Other Firms in Nigeria & 9 & 61.54 & 0 & 0.00 \\
\hline 3. JV's & 14 & 84.62 & 4 & 30.00 \\
\hline 4. Imports & 6 & 30.77 & 15 & 10.00 \\
\hline 5. Smuggled Goods & 3 & 23.08 & 7 & 70.00 \\
\hline $\begin{array}{l}\text { WONF }=\text { Wholly Owned } N \\
J V=\text { Joint Venture }(\text { with }\end{array}$ & $\begin{array}{l}\text { geria } \\
D C N\end{array}$ & & & \\
\hline
\end{tabular}




\section{Table 5: Sources of Capital Equipment by Major Country or Region}

Primary source

of capital eqpt:

1. Home Country

2. Pacific Rim

3. Western Europe

4. USA

5. Japan

6. Eastern Europe

TOTAL

17

100.0

WONF

\begin{tabular}{rrrr}
\multicolumn{1}{c}{ JV } & \multicolumn{2}{c}{ WONF } \\
\hline$\#$ & \multicolumn{1}{c}{ \% } & $\#$ & \% \\
\hline 2 & 11.8 & 0 & 0.0 \\
0 & 0.0 & 0 & 0.0 \\
10 & 58.8 & 15 & 100.0 \\
3 & 17.6 & 0 & 0.0 \\
2 & 11.8 & 0 & 0.0 \\
0 & 0.0 & 0 & 0.0
\end{tabular}

$\begin{array}{lll}17 & 100.0 & 100.0\end{array}$

WONF $=$ Wholly Owned Nigerian Firm

$J V=$ Joint Venture (with a DC MNE)

Source: Primary data

\section{$\underline{\text { Table } 6 \text { : Adaptation of Equipment }}$}

"When your company imports machinery and equipment, is it necessary to adapt or make technical adjustments to these machinery in order for them to work adequately and efficiently in Nigeria?"

\begin{tabular}{lrrrr} 
& \multicolumn{2}{c}{ JV } & \multicolumn{2}{c}{ WONF } \\
\hline & \multicolumn{1}{c}{$\#$} & \multicolumn{1}{c}{$\%$} & $\#$ & \% \\
\hline 1. Always Adapt & 1 & 5.9 & 8 & 53.3 \\
2. Frequently Adapt & 0 & 0.0 & 6 & 40.0 \\
3. Occassionally Adapt & 15 & 88.2 & 0 & 0.0 \\
4. Never Adapt & 1 & 5.9 & 1 & 6.6 \\
5. Do Not Use Imported Eqpt 0 & 0.0 & 0 & 0.0
\end{tabular}

$\begin{array}{lllll}\text { TOTAL } & 17 & 100.0 & 15 & 100.0\end{array}$

WONF $=$ Wholly Owned Nigerian Firm

$J V=$ Joint Venture (with a DC MNE)

Source: Primary data 


\section{Table 7 : Ratio of Expatriates to Nigerian Technical Personnel}

Number of Expatriate Engineers and Technicians Divided by the Number of Nigerian Engineers and Technicians

\begin{tabular}{lrrrr} 
& \multicolumn{2}{c}{ JV } & \multicolumn{2}{c}{ WONF } \\
\hline & $\#$ & \% & $\#$ & \% \\
\hline 1. Less than 20\% & 3 & 17.6 & 15 & 100.0 \\
2. Between 20 and 50\% & 12 & 70.6 & 0 & 0.0 \\
3. Between 50 and 100\% & 2 & 11.8 & 0 & 0.0 \\
4. Over 100\% & 0 & 0.0 & 0 & 0.0 \\
TOTAL & 17 & 100.0 & 15 & 100.0 \\
& & & \\
WONF = Wholly Owned Nigerian Firm & & & \\
JV = Joint Venture (with a DC MNE) & & & \\
Source : Primary data & & & &
\end{tabular}

Table 8: Sources of Raw Materials by Major Country or Region

\begin{tabular}{llrrr} 
Primary Source & \multicolumn{2}{c}{ JV } & \multicolumn{2}{c}{ WONF } \\
\hline of Raw Materials & $\#$ & \multicolumn{1}{c}{$\%$} & $\#$ & \% \\
\hline 1. Home Country & 0 & 0.0 & 0 & 0.00 \\
2. Pacific Rim & 0 & 0.0 & 0 & 0.00 \\
3. Western Europe & 9 & 52.9 & 12 & 80.00 \\
4. USA & 0 & 0.0 & 0 & 0.00 \\
5. Japan & 7 & 41.8 & 3 & 20.00 \\
6. Eastern Europe & 1 & 5.9 & 0 & 0.00 \\
TOTAL & 17 & 100.0 & 15 & 100.00 \\
& & & & \\
WONF = Wholly Owned Nigerian Firm & & & \\
JV = Joint Venture (with a DC MNE) & & & \\
& & & & \\
Source : Primary data & & & &
\end{tabular}




\footnotetext{
${ }^{1}$ The phrases 'third world multinational', 'DC MNE' and third world Joint Ventures (JV) will be used interchangeably throughout this paper.

${ }^{2}$ Biersteker (1987) presents a thorough analysis of the perceptions and objectives that led to the evolution of the indigenisation policy as well as its outcomes.

${ }^{3}$ Author's estimate, based on Lawn (1988) and adjusted to allow for 'fronting' - an expression that refers to the tendency for foreign investors to own and control firms that are ostensibly registered to either a Nigerian partner, or a holding company of a third nationality. This is done to circumvent either Nigerian government restrictions on foreign ownership, or, where the company is registered in a third country, to avoid high taxes on foreign profits and other investment disincentives in the home country. There exist quite a few firms in which the country of origin of the foreign parent is registered as British, although control of the firm is in the hands of management of a developing country descent.
}

${ }^{4}$ In 1982 the exchange rate of the Nigerian Naira was N1 = \$1.492 (end of 1982). Thereafter the Nigerian Naira continued to decline in value and by the end of 1986 it stood at N1 $=0.3015$ and has continued to decline. It is for reasons of comparison, therefore, that the values given in this paper are denominated in Nigerian Naira.

${ }^{5}$ Central Bank of Nigeria, Economic and Financial Review, September 1984.

${ }^{6} 60 \%$ of all inputs for the manufacturing industry are estimated to be imported - EIU Country Profile, 1989-90.

${ }^{7}$ A possible explanation for the increased interest of DC firms in direct investment in Nigeria, and the corresponding decrease amongst industrialised country firms is the relative risk of the Nigerian market compared with the home market. The European firms might expect a higher return on investment given the difference in ethos and socio-cultural environment vis-a-vis their home country, whereas the developing country require a lower premium on their investment, given that they perceive the uncertainty of the investment as being similar to their home country - an argument, in other words, based on the opportunity cost of the investment.

${ }^{8}$ Authors estimates, based on interviews.

9 Foreign companies can now hold a majority stake in any new Nigerian venture except oil prospecting, insurance and mining, although they must have a minimum capital outlay of N20 million

${ }_{10}$ Author's estimate, based on corporate interviews

${ }^{11}$ For purposes of this paper, foreign firms and JV's are considered to be synonymous, given the Nigerian governments restriction at that time on foreign equity in order to prevent wholly owned foreign subsidiaries.

${ }^{12}$ Consisting of all the necessary technology elements including capital equipment, sources of intermediate goods, spare parts and the technologists necessary to efficiently utilise it.

${ }^{13}$ It is possible that some of these firms may have arms length agreements with foreign firms, but we were unable to control for this.

14 There was a strong reluctance by the firms involved to provide us with information, despite reassurances of confidentiality. Many managers, while willing to speak with us initially, insisted after reading the questionnaire that it would have to be cleared with their board of directors.

${ }_{16}^{15}$ Specific country of origin not stated in the interests of confidentiality.

16 There are between 100 and 200 firms that are controlled by DC MNE's. It is difficult to make a more accurate estimate due to the lack of published data, as well as the pronounced use of 'fronting'.

17 Another example of this is given in Ash (1988: 7), of a fishing equipment manager who paid 25\% excise duties on fishing nets, whereas imported nets faced an import duty of 5\%

${ }^{18}$ Masini et al (1980) describe 3 case-studies of multinationals which illustrate the difficulties of scaling down production, as well as the conflict between replacing the capital factor by the work factor to create more 'appropriate' technology, and the tendency towards increasing automation to increase efficiency - see especially pg 147-152.

${ }^{19}$ At least one WON firm maintained a small expatriate technical staff as well as retaining the services of a foreign maintenance firm. 
${ }^{20}$ A similar point is made by Villela (1983) on multinationals from Brazil. 